\title{
IGFBP6 wt Allele
}

National Cancer Institute

\section{Source}

National Cancer Institute. IGFBP6 wt Allele. NCI Thesaurus. Code C52286.

Human IGFBP6 wild-type allele is located within $12 q 13$ and is approximately $5 \mathrm{~kb}$ in length.

This allele, which encodes insulin-like growth factor-binding protein 6 , is involved in the regulation of insulin-like growth factor interactions, cellular proliferation and apoptosis. 